This pre-print is under review at the journal Terra Nova and is deposited on the EarthArXiv platform.

Extension at the coast of the Makran subduction zone (Iran)

By

Raphaël Normand (raphnormand@gmail.com), Guy Simpson ${ }^{1}$ (guy.simpson@unige.ch) and Abbas Bahroudi²(bahroudi@ut.ac.ir)

1 Department of Earth Sciences, University of Geneva, Rue des Maraîchers 13, CH-1205 Genève.

2 Exploration department, School of Mining Engineering, University of Tehran, Northern Kargar avn, P.O. Box 11365-4563, Tehran, Iran. 


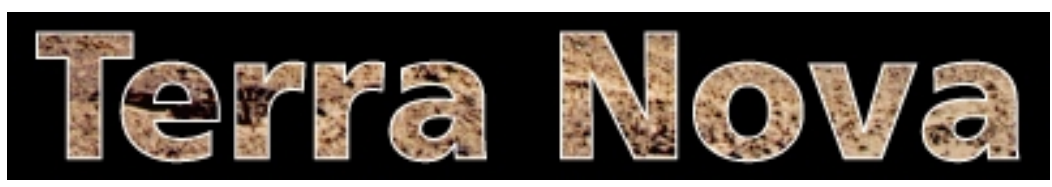

\section{Extension at the coast of the Makran subduction zone (Iran)}

\begin{tabular}{|r|l|}
\hline Journal: & Terra Nova \\
\hline Manuscript ID & TER-2019-0027.R1 \\
\hline Diley - Manuscript type: & Paper \\
\hline Author: & 13 -May-2019 \\
\hline & $\begin{array}{l}\text { Nomplete List of Authors: } \\
\text { of Earth Sciences } \\
\text { Simpson, Guy; University of Geneva Faculty of Science, Department of } \\
\text { Bahroudi, Abbas; University of Tehran, Exploration Department, School } \\
\text { of Mining Engineering }\end{array}$ \\
\hline Keywords: & $\begin{array}{l}\text { Normal faults, Subduction zone, Postseismic relaxation, Makran, } \\
\text { Dynamic Coulomb Wedge }\end{array}$ \\
\hline
\end{tabular}




\title{
Extension at the coast of the Makran subduction zone (Iran)
}

\author{
Raphaël Normand ${ }^{1}$, Guy Simpson ${ }^{1}$ and Abbas Bahroudi ${ }^{2}$ \\ ${ }^{1}$ Department of Earth Sciences, University of Geneva, Rue des Maraîchers 13, CH-1205 Genève. \\ 5 2Exploration department, School of Mining Engineering, University of Tehran, Northern Kargar avn, P.O. Box 11365-4563, \\ Tehran, Iran.
}

\begin{abstract}
In the Makran subduction zone, earthquake focal mechanisms and geodetic data indicate that the deforming prism currently experiences N-S compression. However, paleostress inversions performed on normal faults observed along the coast reveal local stress components consistent with NS extension. Previously proposed mechanisms such as gravitational collapse are not in line with N-S compression and surface uplift. We propose that the observed kinematics result from transient stress reversals following large earthquakes. During the interseismic period (now), the region experiences N$\mathrm{S}$ compression. However, following a large reverse rupture on the subduction interface, stresses in the 15 inner wedge relax, enabling a brief period of extensional faulting before a compressive stress state is reestablished. This mechanism, observed in other subduction zones, requires low overall stresses in the upper plate and that the margin ruptures in large megathrust earthquakes that result in nearly complete stress drops.
\end{abstract}




\section{Introduction}

Subduction plate boundaries are areas of intense folding and thrusting, emphasizing the general state of compressive stress in the overriding plate. However, as observations accumulate, it becomes increasingly clear that this picture is oversimplified for some active margins. For example, several subduction zones have normal faults in the upper plate, indicating extension in the direction of subduction (e.g., Adam and Reuther, 2000). Various mechanisms have been proposed to explain margin-normal upper plate extension, including subduction erosion (e.g., Armijo and Thiele, 1990; Sage et al., 2006), sediment underplating (Platt et al., 1985), gravitational collapse (e.g., Pettinga, 2010) and coseismic relaxation (e.g., Wang and Hu, 2006; Hardebeck, 2012). Regardless of the mechanism, the occurrence of upper plate extension in subduction zones demonstrate a degree of stress complexity going beyond the compression shown by long-term plate convergence.

In this manuscript, we describe field evidence for widespread normal faulting in the Makran subduction zone that indicates margin-normal extension in the upper plate. These kinematics oppose those in the accretionary prism located south of the studied region, where numerous margin-parallel thrusts are observed (Kopp et al., 2000; Grando and McClay, 2007; Smith et al., 2012). They also oppose the kinematics of regions situated to the north, which are currently experiencing shortening in the direction of convergence, accommodated by folding and thrusting (Haghipour et al., 2012; Burg et al., 2013). Our investigation focuses on the coastal strip of the Markan where normal faults are commonly observed (e.g., Hosseini-Barzi and Talbot, 2003; Ellouz-Zimmermann et al., 2007; Grando and McClay, 2007; Burg et al., 2013; Ruh, 2017; Normand et al., 2019b). We measured more than 200 normal faults, which we use to reconstruct the paleostress conditions at the time of their formation. We compare these conditions with those implied by GPS measurements and earthquake focal mechanisms in an attempt to explain their origin. 


\section{Geological setting}

The Makran is an east-west trending belt located in southern Iran and Pakistan involving northward underthrusting of an oceanic portion of the Arabian plate below the continental plate of Eurasia (Fig. 1a). This region hosts one of the widest and thickest modern accretionary prisms on Earth, extending from the trench located $80-150 \mathrm{~km}$ offshore to $250 \mathrm{~km}$ inland. The offshore part of the prism accommodates most of the relative compression between the two plates, where seismic profiles reveal the presence of numerous thrusts and folds (Grando and McClay, 2007; Smith et al., 2012). However, some convergence is also being accommodated within the emerged part of the prism, as evidenced by the presence of deformed late Quaternary fluvial and marine terraces (Haghipour et al., 2012; Normand et al., 2019b). In addition to this compressional deformation, a narrow region near the coast is characterized by the presence of normal faults (e.g., Hosseini-Barzi and Talbot, 2003; Burg et al., 2013; Dolati and Burg, 2013) and seismic sections reveal the presence of south-dipping listric normal faults about $50 \mathrm{~km}$ offshore of the study area (Ellouz-Zimmermann et al., 2007; Grando and McClay, 2007). Both numerical modelling and sand-box experiments suggest that these major listric faults root into the main decollement level and are caused by gravitational collapse of the prism (EllouzZimmermann et al., 2007; Ruh, 2017).

The Makran has experienced relatively few large historical earthquakes in comparison to other subduction zones. The last great thrust event in the region was a Mw 8.1 in 1945, which ruptured the plate interface beneath the Pakistan coast (Fig. 1b) (Byrne et al., 1992). The Iranian segment of the Makran has not ruptured in the last $\sim 500$ years (Heidarzadeh et al., 2008; Musson, 2009). However, most authors agree, based on geophysical properties and the observation of paleoseismic evidences, that the western Makran has the potential to produce large subduction earthquakes (e.g., Rajendran et al., 2013; Smith et al., 2013; Penney et al., 2017; Schneider, 2018), and the threat related to potential Makran earthquakes and associated tsunamis is considered serious (UNESCO-IOC, 2019).

\section{Present day kinematics from GPS and focal mechanisms}

Geodetic data from GPS stations on the Eurasian plate show SSW convergence relative to a fixed Arabian plate, at a rate of $\sim 2 \mathrm{~cm} / \mathrm{y}$ (Fig. 1b, 1c) (Vernant et al., 2004; Bayer et al., 2006; Masson et al., 
2007; Khan et al., 2008; Peyret et al., 2009; Walpersdorf et al., 2014; Frohling and Szeliga, 2016; Penney et al., 2017). This rate progressively decreases from $\mathrm{N}$ to $\mathrm{S}$ (Fig. 1b, 1c), indicating that the coastal portion of the Makran is currently accumulating N-S compressive strain. Stress inversion derived from the focal mechanisms of recent Makran earthquakes also indicate a compressive $\sigma_{1}$ oriented parallel to the direction of convergence (Fig. 2) (Dolati and Burg, 2013). Tectonic surface uplift, at rates ranging between 0.05 and $1.5 \mathrm{~mm} / \mathrm{yr}$ over the Late Pleistocene, is emphasized by the presence of marine terraces exposed along the coast (Normand et al., 2019b).

\section{Normal faulting in the study area}

This study focuses on structural observations in the vicinity of Chabahar, a $30 \times 15 \mathrm{~km}$ headland where Pliocene rocks locally host uplifted Pleistocene terraces and associated sediments (Fig. 3). The Chabahar headland is bound by a series of NE-SW and NW-SE striking normal faults that dip towards the headland (Fig. 3, 4a). Thus, even though the headland stands above the surrounding topography and is regionally uplifted, it is actually a downthrown fault block. The reason it stands high is due to exposure of resistant sandstones, whereas the surrounding footwall is comprised of easily erodible marls. The age of the offset units (Upper Miocene footwall versus Pliocene hanging wall) (Samadian et al., 1996) and ridge-in-groove structures on the fault plane indicate normal movement (Fig. 4a, field pictures A-G, (Normand et al., 2019a)).

In addition to these relatively major normal faults (with throws exceeding $50 \mathrm{~m}$ ), the Chabahar headland is cut by numerous smaller-displacement (a few meters maximum) normal faults (Fig. 3, 4). Most of these faults strike parallel to the coastline and the trench and are south-dipping at angles of $50^{\circ}-70^{\circ}$ (Fig. $5 \mathrm{a}, 5 \mathrm{~b}$ ), while a relatively smaller subset of faults have strikes of NE-SW and NW-SE (Fig. 3, Fig. 5a). We did not observe any clear evidence for reverse motion, while about half of the faults (121) showed evidence for normal displacements, based on the offset of distinct beds (Fig. 4b, 4c, 4d), offset of terraces surfaces (Fig. 4d, 4e), normal drag adjacent to faults (Fig. 4b), structures on the fault plane (Fig. 4f, 4g) or the age of the offset formations (Fig. 4a). However, previous work mention possible episodes of normal fault reversal (Hosseini-Barzi and Talbot, 2003; Grando and McClay, 2007). 
The normal faults on the Makran coast have apparently been active for a prolonged period of time. In some cases, the normal faults offset Pliocene sediments but are truncated by Late Pleistocene terraces, indicating that they have remained inactive since terrace formation (Fig. 4d). In other cases, faults offset the late Pleistocene terraces, indicating that they have been active in recent times (i.e. since the emplacement of the Late Pleistocene terrace deposits).

\section{Stress inversion}

We used fault geometry measurements made on Chabahar headland (Normand et al., 2019a) to invert for the paleostress at the time faults were formed using the Win-Tensor 5.8.8 software (Fig. 5) (Delvaux and Sperner, 2003) (see supplementary data A). Assuming all faults are normal, our results show that $\sim 85 \%$ of the faults are consistent with a stress state whereby $\sigma_{1}$ is vertical, $\sigma_{3}$ is approximately horizontal and oriented $\sim 20^{\circ} \mathrm{N}$ and $\sigma_{2}$ is parallel to the trench (Fig. 5c). This stress state is exactly the opposite of that inferred from GPS (Fig. 1b) and earthquake focal mechanisms (Fig. 2).

110 The estimated $\mathrm{R}$ value (where $\mathrm{R}=\left(\sigma_{2^{-}}-\sigma_{3}\right) /\left(\sigma_{1}-\sigma_{3}\right)$ (Angelier, 1984)) of 0.18 indicates that $\sigma_{2}$ and $\sigma_{3}$ have similar values (to within 20\%), though both are much smaller than $\sigma_{1}$ (See Fig. 5c, Mohr diagram). This suggests that $\sigma_{2}$ and $\sigma_{3}$ could locally switch, which might explain the occurrence of a minor subset of normal faults with different orientations (Fig. 3, Fig. 5a). The downthrown fault block forming the Chabahar headland could also be an orthorhombic fault system consistent with N-S extension (e.g., Reches, 1978; Hosseini-Barzi and Talbot, 2003).

\section{Discussion}

We have shown that despite GPS data (Fig. 1) and focal mechanisms (Fig. 2) suggesting that the coastal Makran is currently experiencing N-S compression (along with exposed marine terraces that show it is undergoing regional surface uplift), normal faults observed onshore near the coastline indicate N-S extension. Here, we discuss possible explanations for these opposing kinematics.

According to the critical wedge theory, the stress state in a deforming frictional prism adjusts itself to balance the applied tectonic stresses, shear resistance to sliding on the decollement and gravity (Davis et al., 1983; Dahlen, 1984). For the Makran wedge that has a low taper (ca. $5^{\circ}$ ), critical wedge theory 
predicts a horizontally-compressive stress state and deformation accommodated by shallow dipping conjugate thrusts. Although this is consistent with deformation near the toe of the prism, it is not in line with extensional faulting observed at the coast, especially northwards of the shelf break, where the taper is further reduced (Fig. 1c). One possible explanation for this extensional deformation is to advocate a change in conditions with time, which might cause the wedge to locally readjust (Dahlen, 1984). For example, if the basal decollement under the coastal region suddenly experienced a decrease in frictional resistance (e.g., due to an increase in fluid overpressure), the local wedge taper would be too steep for the new conditions, which is predicted to drive the wedge into extension to reduce the slope of the topography and achieve a new equilibrium (see Fig. 12 and 13 of Dahlen, 1984). Extensional faulting could also result from sediment underplating, causing steepening of the taper followed by gravitational collapse (Platt et al., 1985), facilitated by an increase in fluid overpressure with depth (Ruh, 2017) and/or by sediment loading (Ellouz-Zimmermann et al., 2007). Numerical models and sand-box experiments have shown that these phenomena could be cause of the large listric normal faults observed near the Makran shelf break with seismic reflection (Ellouz-Zimmermann et al., 2007; Grando and McClay, 2007; Ruh, 2017). However, if these mechanisms were the origin for the relatively minor, recently active normal faults observed onshore in this study, we would expect GPS measurements to indicate N-S extension and subsidence (Ruh, 2017), rather than compression and uplift.

One way to reconcile the apparently conflicting kinematics observed in the Makran coastal strip is to consider the potential influence of large megathrust earthquakes (Wang and $\mathrm{Hu}, 2006$ ), such as the Mw 8.1 event in the eastern Makran in 1945 (Byrne et al., 1992). During great earthquakes, the inner part of the wedge, situated directly above the ruptured interface (i.e., the coastal region in the case of the Makran, Fig. 1b), is expected to experience coseismic stress release (Fig. 6b) (Wang and Hu, 2006; Wang et al., 2012). If friction on the subduction interface during rupture drops to a sufficiently low value, the portion of the wedge situated directly above the ruptured area (the inner wedge) may be driven into a state of critical extension, leading to normal faulting (Fig. 6b). After an earthquake, the inner wedge will progressively revert to compression due to locking of the subduction interface (Wang 
et al., 2012) (Fig. 6a). Even so, the stress state in this part of the wedge may remain in the stable domain (i.e., and is thus insufficient to induce thrust faulting) throughout the entire interseismic period (Wang and $\mathrm{Hu}, 2006$ ). Indeed, episodes of normal fault reversal have been interpreted to have occurred in the coastal Makran (Hosseini-Barzi and Talbot, 2003; Grando and McClay, 2007), even though no true reverse faults were observed in this region.

This scenario is compatible both with the observation of present day compression in the wedge (since we currently observe the interseimic stress state) and the local presence of normal faults in the inner wedge, which presumably form only during a brief period of time during and immediately after megathrust earthquakes above the ruptured area. Moreover, our hypothesis is consistent with recent observations showing normal fault aftershocks in the upper overthrust plate following the Sumatra 2004, Maule 2010 and Tōhoku 2011 megathrust earthquakes (Dewey et al., 2007; Farías et al., 2011; Kato et al., 2011; Hardebeck, 2012). The observation of coseismic rotation of the principal stress axes implies that the mentioned earthquakes caused a near complete stress drop, which was sufficient to drive the surrounding crust into extension (Hasegawa et al., 2011; Hardebeck, 2012) and possibly trigger volcanic eruptions (e.g., Walter and Amelung, 2007).

Our mechanism proposed to explain kinematics in the inner wedge requires that the western Makran does indeed experience occasional large megathrust earthquakes, as is known to occur in the eastern Makran. This mechanism also requires extremely low frictional resistance on the subduction interface during rupture and a low overall stress state in the inner wedge (Wang, 2000). Both of these features are consistent with numerical experiments (Ruh, 2017) and evidence for high fluid pressures in the Makran wedge such as an overall low wedge taper (White and Louden, 1982; Smith et al., 2012), the presence of mud volcanos (e.g., Snead, 1964; Delisle, 2004), overpressured shale layers in the prism (Ruh et al., 2018) and other geological evidences of fluid overpressure (Normand et al., 2019a).

\section{Conclusions}

Our field investigation in the Makran subduction zone has revealed widespread evidence for normal faults oriented parallel to the coast, implying extension of the upper plate in the direction of 
subduction. These kinematics are the opposite from those indicated by GPS measurements and earthquake focal mechanisms, which indicate present day N-S compression. We postulate that these kinematics reflect stress changes linked to major earthquakes on the subduction interface. According the interseismic period, whereas it experiences a brief period of extension as stresses are released during large ruptures on the subduction interface. This is permitted if near-complete stress drop occurs during the megathrust event, implying a weak subduction interface, which is supported by evidence for high pore fluid pressures in the Makran prism.

\section{Acknowledgements}

This work was funded by the Swiss National Science Foundation, project $n^{\circ} 200021$ 155904. We are grateful to Reza Ensani, Feisal Arjomandi, Nurrudin Mazarzehi, Yousef Adeeb and Gholamreza Hosseinyar for helping us with logistics in Iran and accompanying us in the field. The authors declare that they have no conflict of interest.

\section{Data availability}

All data collected in this study is freely available in the following data repository: https://doi.org/10.5281/zenodo.2559480 (Normand et al., 2019a).

\section{References}

Adam, J., and Reuther, C., 2000, Crustal dynamics and active fault mechanics during subduction erosion . Application of frictional wedge analysis on to the North Chilean Forearc: Tectonophysics, 321, 297-325, doi:10.1016/S00401951(00)00074-3.

Allmendinger, R.W., Cardozo, N., and Fisher, D.M., 2013, Structural Geology Algorithms: Vectors and Tensors: Cambridge, England, Cambridge University Press, 289 p., doi:10.1017/CBO9780511920202.

Angelier, J., 1984, Tectonic analysis of fault slip data sets: J. Geophys. Res., 89, 5835-5848, doi:10.1029/JB089iB07p05835.

Armijo, R., and Thiele, R., 1990, Active faulting in northern Chile: ramp stacking and lateral decoupling along a subduction plate boundary? Earth Planet. Sci. Lett., 98, 40-61, doi:10.1016/0012-821X(90)90087-E.

Bayer, R., Chery, J., Tatar, M., Vernant, P., Abbassi, M., Masson, F., Nilforoushan, F., Doerflinger, E., Regard, V., and Bellier, O., 2006, Active deformation in Zagros-Makran transition zone inferred from GPS measurements: Geophys. J. 
Int., 165, 373-381, doi:10.1111/j.1365-246X.2006.02879.x.

Burg, J.-P., Dolati, A., Bernoulli, D., and Smit, J., 2013, Structural style of the Makran Tertiary accretionary complex in SEIran, in Al Hosani, K., Roure, F., Ellison, R., and Lokier, S. eds., Lithosphere Dynamics and Sedimentary Basins: The Arabian Plate and Analogues, Springer, p. 239-259, doi:10.1007/978-3-642-30609-9_12.

Byrne, D.E., Sykes, L.R., and Davis, D.M., 1992, Great Thrust Earthquakes and Aseismic Slip Along the Plate Boundary of the Makran Subduction Zone: J. Geophys. Res. Earth, 97, 449-478, doi:10.1029/91JB02165.

Cardozo, N., and Allmendinger, R.W., 2013, Computers \& Geosciences Spherical projections with OSXStereonet: Comput. Geosci., 51, 193-205, doi:10.1016/j.cageo.2012.07.021.

Dahlen, F.A., 1984, Noncohesive Critical Coulomb Wedges: An Exact Solution: J. Geophys. Res., 89, 10'125-10'133.

Davis, D., Suppe, J., and Dahlen, F.., 1983, Mecanics of Fold-and-Thrust Belts and Accretionary Wedges: J. Geophys. Res., 88, 1153-1172.

Delisle, G., 2004, The mud volcanoes of Pakistan: Environ. Geol., 46, 1024-1029, doi:10.1007/s00254-004-1089-x.

Delvaux, D., and Sperner, B., 2003, Stress tensor inversion from fault kinematic indicators and focal mechanism data: the TENSOR program. In: New Insights into Structural Interpretation and Modelling (D. Nieuwland Ed.). (D. Nieuwland, Ed.): Geol. Soc. London, Spec. Publ., 212, 75-100, doi:10.1144/GSL.SP.2003.212.01.06.

Dewey, J.W., Ghoy, G., Presgrave, B., Sipkin, S., Tarr, A.C., H, B., Earle, P., and Wald, D., 2007, Seismicity associated with the Sumatra-Andaman Islands earthquake of 26 December 2004: Bull. Seismol. Soc. Am., 97, S25-S42, doi:10.1785/0120050626.

Dolati, A., and Burg, J.-P., 2013, Preliminary fault analysis and paleostress evolution in the Makran Fold-and-Thrust Belt in Iran, in Al Hosani, K., Roure, F., Ellison, R., and Lokier, S. eds., Lithosphere Dynamics and Sedimentary Basins: The Arabian Plate and Analogues, Springer, p. 261-277, doi:10.1007/978-3-642-30609-9_13.

Ellouz-Zimmermann, N., Deville, E., Müller, C., Lallemand, S., Subhani, A.B., and Tabreez, A.R., 2007, Impact of Sedimentation on Convergent Margin Tectonics: Example of the Makran Accretionary Prism ( Pakistan ), in Lacombe, O., Roure, F., Lavé, J., and Vergés, J. eds., Thrust Belts and Foreland Basins, Springer, Berlin, Heidelberg, p. 327-350, doi:10.1007/978-3-540-69426-7_17.

Farías, M., Comte, D., Roecker, S., Carrizo, D., and Pardo, M., 2011, Crustal extensional faulting triggered by the 2010 Chilean earthquake : The Pichilemu Seismic Sequence: Tectonics, 30, 1-11, doi:10.1029/2011TC002888.

Frohling, E., and Szeliga, W., 2016, GPS constraints on interplate locking within the Makran subduction zone: Geophys. J. Int., 205, 67-76, doi:10.1093/gji/ggw001.

Grando, G., and McClay, K., 2007, Morphotectonics domains and structural styles in the Makran accretionary prism, 
offshore Iran: Sediment. Geol., 196, 157-179, doi:10.1016/j.sedgeo.2006.05.030.

Haghipour, N., Burg, J.P., Kober, F., Zeilinger, G., Ivy-Ochs, S., Kubik, P.W., and Faridi, M., 2012, Rate of crustal shortening and non-Coulomb behaviour of an active accretionary wedge: The folded fluvial terraces in Makran (SE, Iran): Earth Planet. Sci. Lett., 355-356, 187-198, doi:10.1016/j.eps1.2012.09.001.

Hardebeck, J.L., 2012, Coseismic and postseismic stress rotations due to great subduction zone earthquakes: Geophys. Res. Lett., 39, 1-6, doi:10.1029/2012GL053438.

Hasegawa, A., Yoshida, K., and Okada, T., 2011, Nearly complete stress drop in the $2011 \mathrm{Mw} 9.0$ off the Pacific coast of Tohoku Earthquake: Earth, Planets Sp., 63, 703-707, doi:10.5047/eps.2011.06.007.

Heidarzadeh, M., Pirooz, M.D., Zaker, N.H., Yalciner, A.C., Mokhtari, M., and Esmaeily, A., 2008, Historical tsunami in the Makran Subduction Zone off the southern coasts of Iran and Pakistan and results of numerical modeling: Ocean Eng., 35, 774-786, doi:10.1016/j.oceaneng.2008.01.017.

245 Hosseini-Barzi, M., and Talbot, C.J., 2003, A tectonic pulse in the Makran accretionary prism recorded in Iranian coastal sediments: J. Geol. Soc. London., 160, 903-910, doi:10.1144/0016-764903-005.

Kato, A., Sakai, S., and Obara, K., 2011, A normal-faulting seismic sequence triggered by the 2011 off the Pacific coast of Tohoku Earthquake: Wholesale stress regime changes in the upper plate: Earth, Planets Sp., 63, 745-748, doi:10.5047/eps.2011.06.014.

Khan, M.A. et al., 2008, Preliminary geodetic constraints on plate boundary deformation on the western edge of the Indian plate from TriGGnet ( Tri-University GPS Geodesy Network ): J. Himal. Earth Sci., 41, 71-87.

Kopp, C., Fruehn, J., Flueh, E.R., Reichert, C., Kukowski, N., Bialas, J., and Klaeschen, D., 2000, Structure of the makran subduction zone from wide-angle and reflection seismic data: Tectonophysics, 329, 171-191, doi:10.1016/S00401951(00)00195-5.

255 Masson, F., Anvari, M., Djamour, Y., Walpersdorf, A., Tavakoli, F., Daignières, M., Nankali, H., and Van Gorp, S., 2007, Large-scale velocity field and strain tensor in Iran inferred from GPS measurements: New insight for the present-day deformation pattern within NE Iran: Geophys. J. Int., 170, 436-440, doi:10.1111/j.1365-246X.2007.03477.x.

Musson, R.M.W., 2009, Subduction in the Western Makran: the historian's contribution: J. Geol. Soc. London., 166, 387391, doi:10.1144/0016-76492008-119.

Normand, R., Simpson, G., and Bahroudi, A., 2019a, Data for: Extension at the coast of the Makran subduction zone (Iran):, doi:10.5281/zenodo.2559480.

Normand, R., Simpson, G., Herman, F., Biswas, R.H., Bahroudi, A., and Schneider, B., 2019b, Dating and morphostratigraphy of uplifted marine terraces in the Makran subduction zone (Iran): Earth Surf. Dyn., 7, 321-344, 
doi:10.5194/esurf-7-321-2019.

Penney, C. et al., 2017, Megathrust and accretionary wedge properties and behaviour in the Makran subduction zone: Geophys. J. Int., 209, 1800-1830, doi:10.1093/gji/ggx126.

Pettinga, J.R., 2010, Three-stage massive gravitational collapse of the emergent imbricate frontal wedge , Hikurangi Subduction Zone, New Zealand: New Zeal. J. Geol. Geophys., 47, 399-414, doi:10.1080/00288306.2004.9515066.

Peyret, M. et al., 2009, Present-day strain distribution across the Minab-Zendan-Palami fault system from dense GPS transects: Geophys. J. Int., 179, 751-762, doi:10.1111/j.1365-246X.2009.04321.x.

Platt, J.P., Leggett, J.K., Young, J., Raza, H., and Alam, S., 1985, Large-scale sediment underplating in the Makran accretionary prism, southwest Pakistan.: Geology, 13, 507-511, doi:10.1130/00917613(1985)13<507:LSUITM>2.0.CO;2.

Rajendran, C.P., Rajendran, K., Shah-hosseini, M., Beni, A.N., Nautiyal, C.M., and Andrews, R., 2013, The hazard potential of the western segment of the Makran subduction zone, northern Arabian Sea: Nat. Hazards, 65, 219-239, doi:10.1007/s11069-012-0355-6.

Reches, Z., 1978, Analysis of faulting in three-dimensional strain field: Tectonophysics, 47, 109-129, doi:10.1016/00401951(78)90154-3.

Ruh, J.B., 2017, Effect of fluid pressure distribution on the structural evolution of accretionary wedges: Terra Nov., 29, 202210, doi:10.1111/ter.12263.

Ruh, J.B., Vergés, J., and Burg, J., 2018, Shale-related minibasins atop a massive olistostrome in an active accretionary wedge setting: Two-dimensional numerical modeling applied to the Iranian Makran: Geology, 46, 791-794, doi:10.1130/G40316.1.

Sage, F., Collot, J.-Y., and Ranero, C.R., 2006, Interplate patchiness and subduction-erosion mechanisms : Evidence from depth-migrated seismic images at the central Ecuador convergent margin: Geology, 34, 997-1000, doi:10.1130/G22790A.1.

Samadian, M.R., Ghomashi, A., Mohebbi, A.R., Jafarian, M.B., Abdoli, M., and Ahmadzadeh Heravi, M., 1996, Geological map of Iran 1:100’000 : Chabahar sheet: Geological Survey of Iran.

Schneider, B., Hoffmann, G., Falkenroth, M., and Grade, J., 2018, Tsunami and storm sediments in Oman : Characterizing extreme wave deposits using terrestrial laser scanning: J. Coast. Conserv., doi:10.1007/s11852-018-0663-4.

Smith, G., McNeill, L., Henstock, I.J., and Bull, J., 2012, The structure and fault activity of the Makran accretionary prism: J. Geophys. Res. Solid Earth, 117, 1-17, doi:10.1029/2012JB009312.

Smith, G.L., McNeill, L.C., Wang, K., He, J., and Henstock, T.J., 2013, Thermal structure and megathrust seismogenic 
potential of the Makran subduction zone: Geophys. Res. Lett., 40, 1528-1533, doi:10.1002/grl.50374.

Snead, R.J., 1964, Active Mud Volcanoes of Baluchistan, West Pakistan: Geogr. Rev., 54, 546-560, doi:10.2307/212981.

UNESCO-IOC, 2019, Summary Statement from the Expert Consultation on Scientific Tsunami Hazard Assessment of the Makran Subduction Zone, 8 March 2019, in Perth, UNESCO/IOC Brochure 2019-3.

Vernant, P. et al., 2004, Present-day crustal deformation and plate kinematics in the Middle East constrained by GPS measurements in Iran and northern Oman: Geophys. J. Int., 157, 381-398, doi:10.1111/j.1365-246X.2004.02222.x.

Walpersdorf, A. et al., 2014, Present-day kinematics and fault slip rates in eastern Iran, derived from 11 years of GPS data: J. Geophys. Res. Solid Earth, 119, 1359-1383, doi:10.1002/2013JB010620.

Walter, T.R., and Amelung, F., 2007, Volcanic eruptions following $M \geq 9$ megathrust earthquakes: Implications of the Sumatra-Andaman volcanoes: Geology, 35, 539-542, doi:10.1130/G23429A.1.

Wang, K., 2000, Stress - strain ' paradox ', plate coupling, and forearc seismicity at the Cascadia and Nankai subduction zones: Tectonophysics, 319, 321-338, doi:10.1016/S0040-1951(99)00301-7.

Wang, K., and Hu, Y., 2006, Accretionary prisms in subduction earthquake cycles: The theory of dynamic Coulomb wedge: J. Geophys. Res., 111, 1-16, doi:10.1029/2005JB004094.

Wang, K., Hu, Y., and He, J., 2012, Deformation cycles of subduction earthquakes in a viscoelastic Earth: Nature, 484, 327332, doi:10.1038/nature11032.

White, R.S., and Louden, K.E., 1982, The Makran continental margin: structure of a thickly sedimented convergent plate boundary, in Watkins, J.S., Drake, C.L. ed., AAPG Special Volumes, Studies in Continental Margin Geology, v. 34, p. $499-518$.

\section{Figure Legends:}

Figure 1. Makran subduction zone. a) Large scale tectonic setting. b) Map showing GPS velocities with a fixed Arabian plate reference. Data based on the compilation by Penney et al. (2017) from the existing literature (see section 3 for references). The square delineates the study area. The dashed line is the approximate northern limit of the accretionary wedge. Shaded areas are estimated rupture areas of the most recent major thrust earthquakes (Byrne et al., 1992). Triangles are active volcanic centers. CF: Chaman fault, HB: Helmand block, LB: Lut block, MF: Minab fault, MR: Murray ridge, ONF: 
Ornach-Nal fault, SF: Sonne fault, SS: Sistan suture, ZT: Zagros thrust. c) N-S profile across the Makran prism (see dashed black line, Fig. 1b). Black line is the topographic profile (ETOPO1) (left scale). The N-S component of geodetic velocities from Fig $1 \mathrm{~b}$ are projected on the profile (right scale). They show progressively slower values towards the coast.

Figure 2. Makran earthquakes between 1945 and 2003 (modified after Dolati and Burg, 2012). (a) Location and focal mechanism of the 28 earthquakes (b) Stereonet (equal area) showing the stress state inverted from the earthquakes shown in (a). Arrows are GPS velocities and their error ellipses, with a fixed Arabian plate (references in Fig. 1), plotted above the plane to show the correlation with the general direction of $\sigma_{1}$.

Figure 3. Structural map of Chabahar headland showing normal faults mapped in the field. Ages of the formations are from the 1:100’000 geological map of Chabahar (Samadian et al., 1996). Marine terrace borders are from Normand et al. (2019b). Letters correspond to the locations of the pictures in Figure 4.

335 Figure 4. Normal faults in the vicinity of Chabahar a) Major normal fault along the northern border of the Chabahar headland. Total height: $\sim 20 \mathrm{~m} .\left(25.387^{\circ} \mathrm{N}, 60.717^{\circ} \mathrm{E}\right)$. b) Normal faults on the Konarak headland. The cliff is $\sim 35 \mathrm{~m}$ high (person circled). $\left(25.352^{\circ} \mathrm{N}, 60.303^{\circ} \mathrm{E}\right)$. c) Normal fault offsetting a horizontal Pliocene sandstone bed $\left(25.391^{\circ} \mathrm{N}, 60.653^{\circ} \mathrm{E}\right)$. d) Normal faults (arrows) offsetting tilted Pliocene beds and an overlying subhorizontal Late Pleistocene marine terrace. The outcrop is $25 \mathrm{~m}$ high. (Lipar lake, $25.259^{\circ} \mathrm{N}, 60.828^{\circ} \mathrm{E}$ ). e) Satellite (Google Earth) image showing normal faults offsetting the marine terraces at Lipar Lake (arrows). f-g) Normal movement indicators on fault planes on the Chabahar headland $(15 \mathrm{~cm}$ pencil circled, tape is in centimeters). The pictures show the fault plane of the hanging wall, where pebbles have been dragged by the upwards motion of the footwall.

Figure 5. Geometry and paleostress state for normal faults on the Chabahar headland. All stereonets are equal area, lower hemisphere projection (Schmidt). Paleostress inversion was performed with WinTensor 5.8.5 software (Delvaux and Sperner, 2003). a) Poles of all 213 fault planes with density contours, plotted with Stereonet 9.5 (Allmendinger et al., 2013; Cardozo and Allmendinger, 2013). b) 
Movement lineation measurements. c) Result of stress inversion after refinement of the main subset containing 181 out of the 213 faults (see supplementary data A).

350 Figure 6. Illustration of the hypothesis for formation of normal faults following large megathrust ruptures. During the interseismic period (a), the subduction interface is locked and the overriding plate is in compression. When the plate boundary ruptures (b), near complete coseismic stress release leads to local normal faulting above the ruptured area, for a short period before a critically compressive stress state is reestablished (back to (a)). 

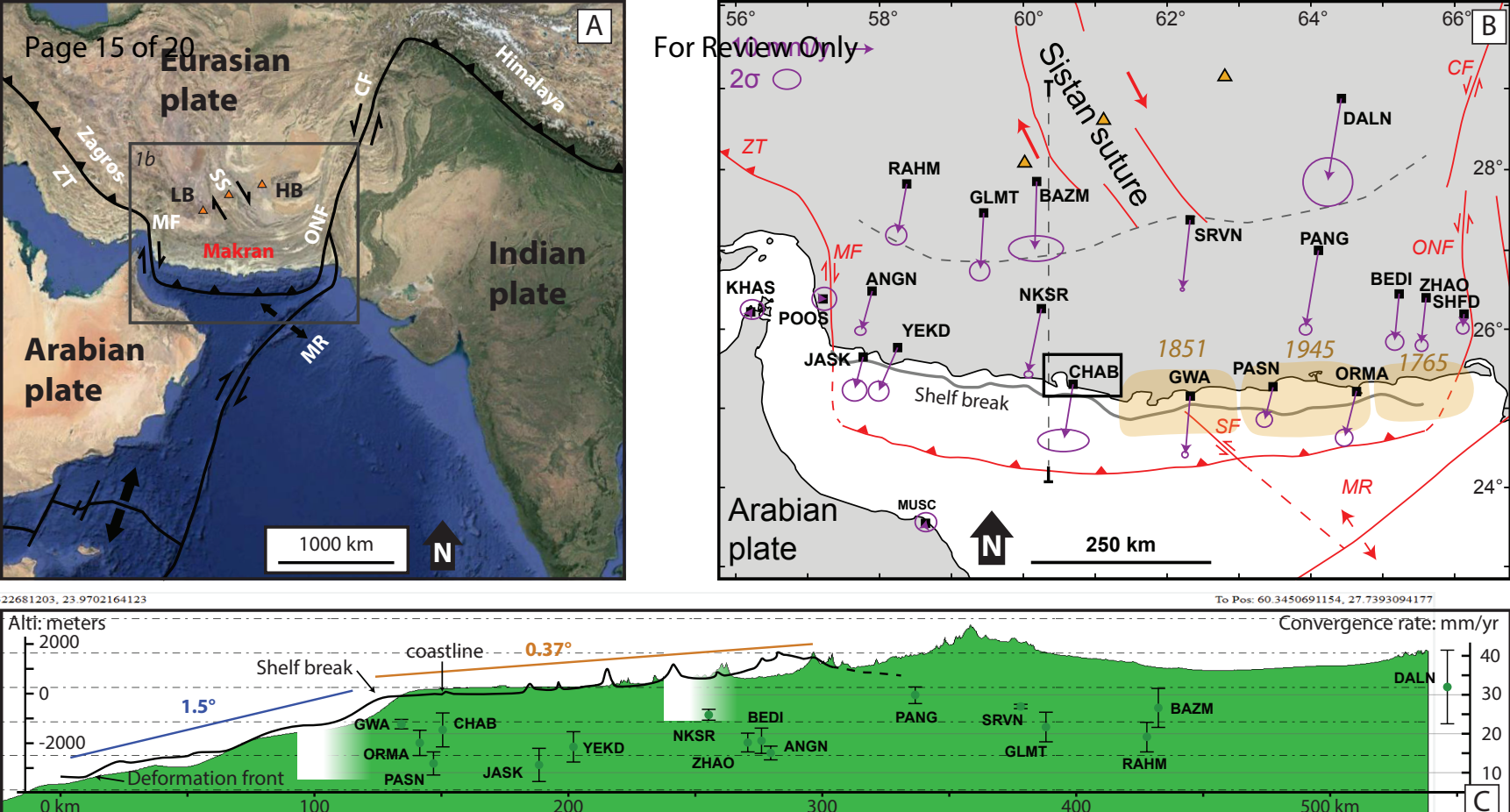

Shelf break
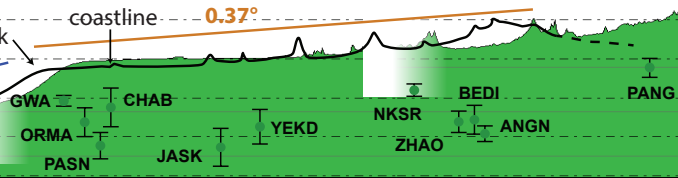

PANG

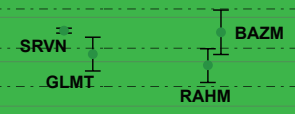

Convergence rate: $\mathrm{mm} / \mathrm{yr}$ $0 \mathrm{~km}$ 200 300 400 


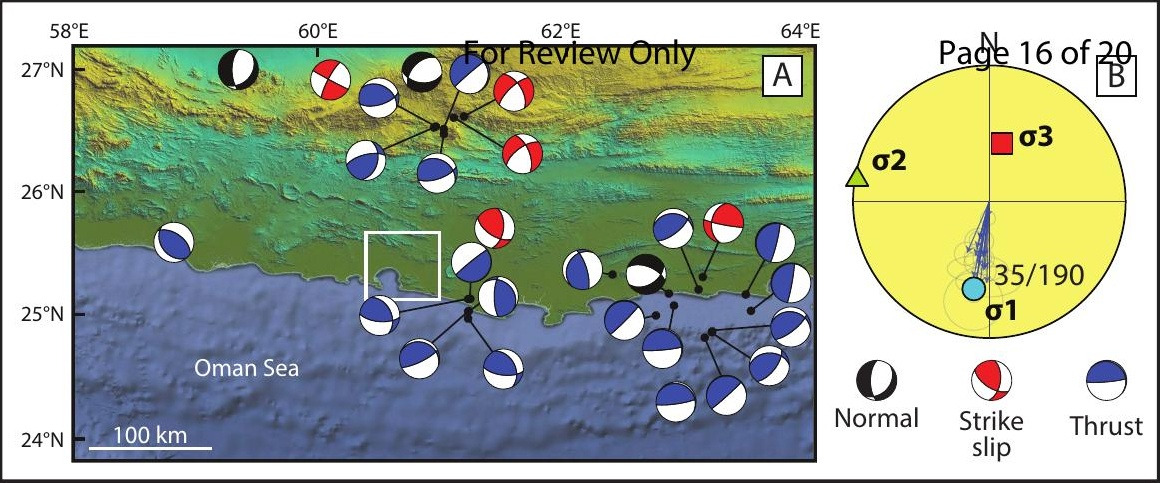




\section{For Review Only}

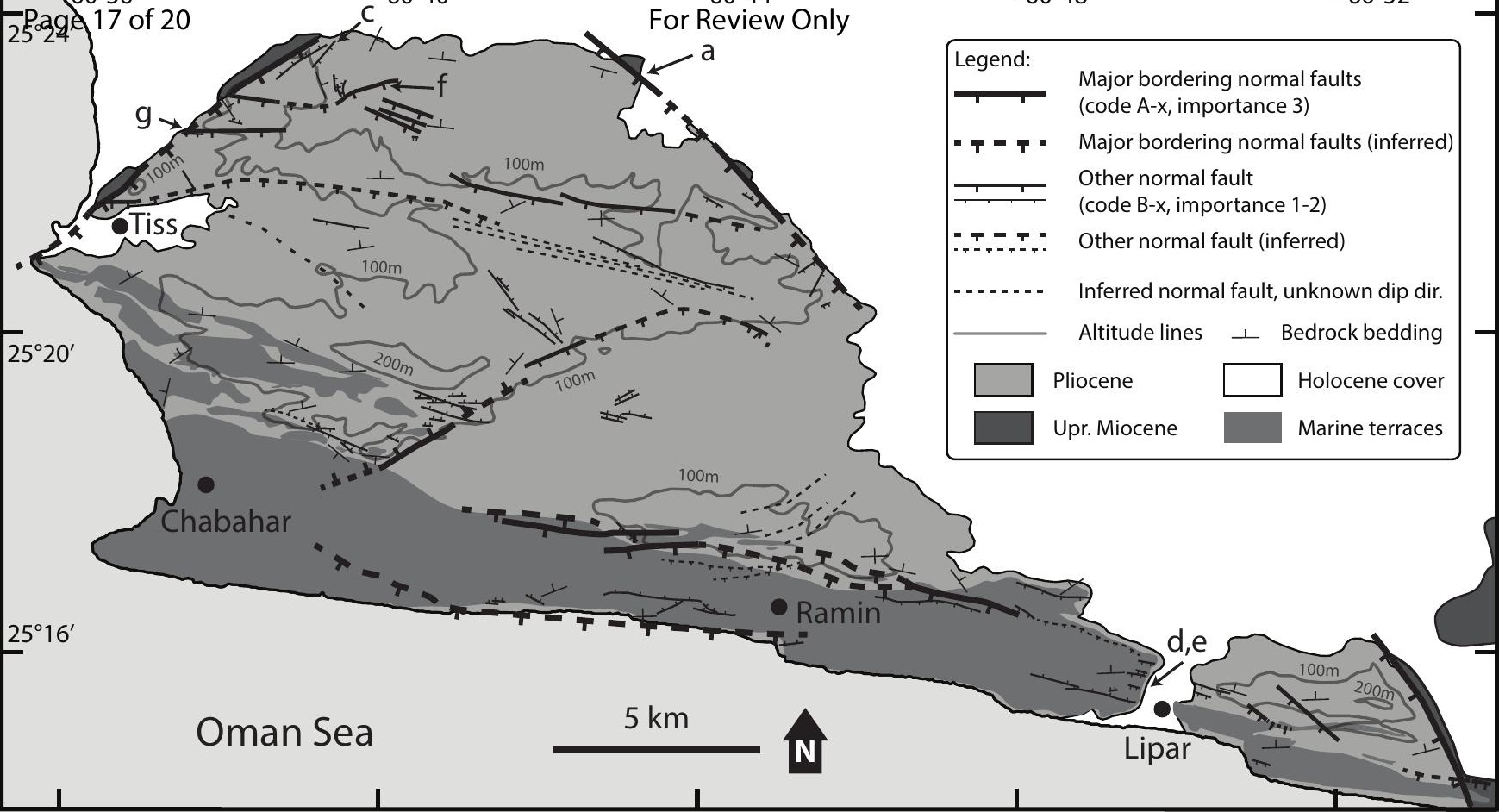



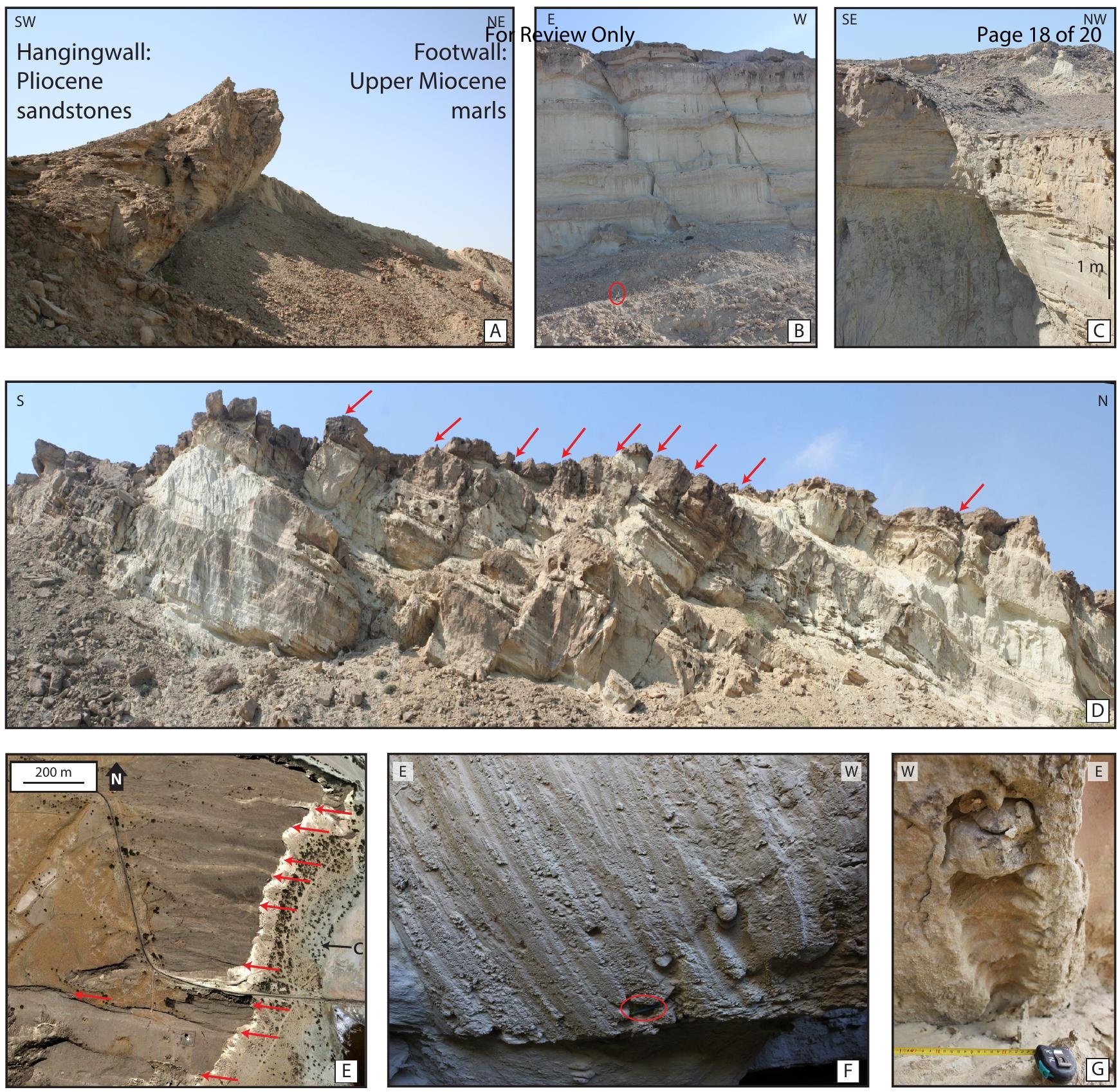

$\mathrm{N}$
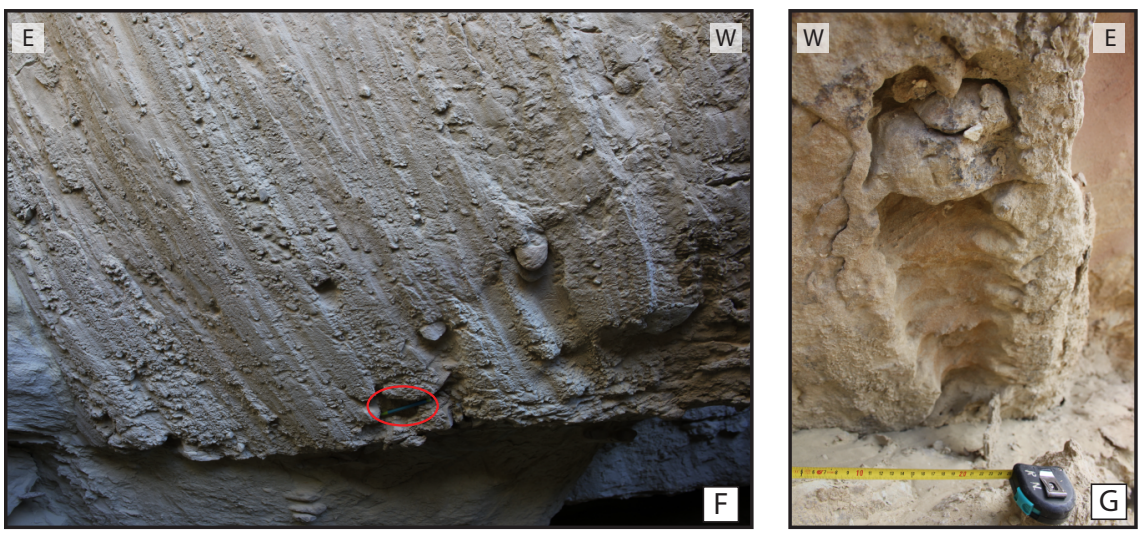
Poles of 213 planes

Page 19 of 20

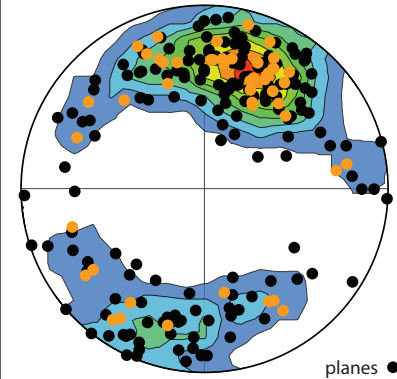

planes + lineations

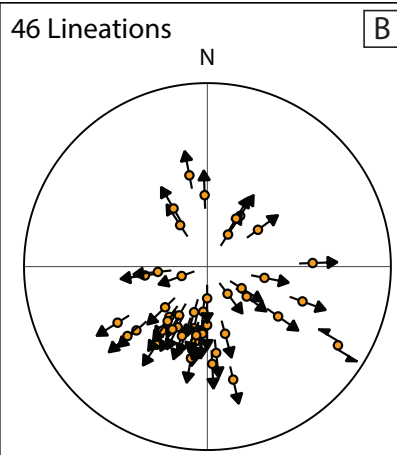

R. Optim. F5

$181 / 213$ faults $\checkmark$ For Review Only

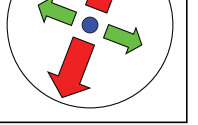

() $\sigma 1: 83 / 159$ (1) $\sigma 2: 05 / 288$ 이 $\sigma 3:$ 05/019 R: 0.18 F5: 0.5 QRw: C QRt: C

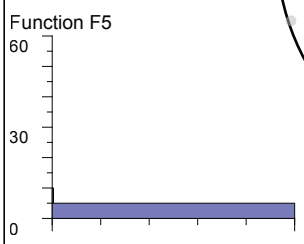

0 Sum of Weights 376

Shear stress magnitude $(T)$

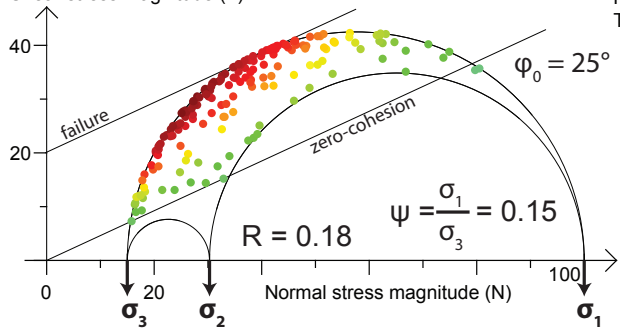

Schmidt Lower

Weight Mode 2 $\mathrm{n} / \mathrm{nt}: 181 / 0$
Normalised Slip Tendency

TsN

Subsets 2 and 3

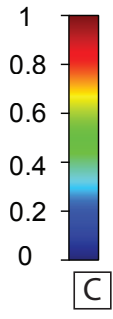




\section{A Interseismic period df kererent) Only Page 20 of 20}

outer-wedge

Sea level inner-wedge

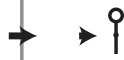

Coastal strip
Eurasian plate

Relaxation

B Coseismic period
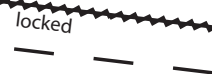

Creep
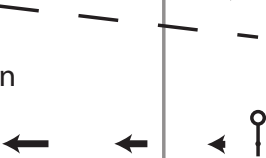

Coastal strip

Eurasian plate

Arabian plate
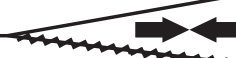
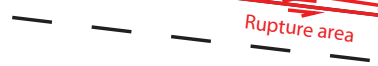

Creep 